\title{
PENINGKATAN KETERAMPILAN KONSTRUKSI DENGAN PENDEKATAN KONSTRUKTIVISME DI KELAS IV SD NEGERI O4 BATANG ANAI KABUPATEN PADANG PARIAMAN
}

\section{Yusnimarniarti}

\begin{abstract}
Abstrak
Pembelajaran konstruksi di SD bertujuan agar peserta didik menjadi cekat, cepat, tepat, dan mampu menciptakan serta mengkreasikan bermacam ragam ide atau gagasan kedalam bentuk vas bunga dengan memanfaatkan bahan alam dan limbah. Berdasarkan hasil observasi yang dilakukan terhadap peserta didik kelas IV SD Negeri 04 Batang Anai, ditemukan bahwa keterampilan konstruksi peserta didik masih rendah. Pengunaan pendekatan konstruktivisme merupakan salah satu cara untuk memecahkan masalah dalam proses pembelajaran keterampilan konstruksi peserta didik. Penelitian yang dilaksanakan merupakan penelitian tindakan kelas dengan menggunakan pendekatan kualitatif dan kuantitatif. Rancangan penelitian ini meliputi: perencanaan tindakan, pelaksanaan tindakan, observasi, dan refleksi. Dalam penelitian ini, peneliti bertindak sebagai praktisi yang berkolaborasi dengan teman sejawat sebagai pengamat. Data dikumpulkan dengan menggunakan lembar observasi, wawancara, dan catatan lapangan. Hasil penelitian menunjukkan bahwa penggunaan pendekatan konstruktivisme terbukti efektif dalam meningkatkan keterampilan konstruksi peserta didik kelas IV SD Negeri 04 Batang Anai. Hal ini terlihat dari peningkatan kualitas dan nilai keterampilan konstruksi yang dihasilkan peserta didik pada setiap pertemuan dalam masing-masing siklus. Peningkatan keterampilan konstruksi peserta didik berimbas pada peningkatan nilai proses dan nilai hasil karya keterampilan konstruksi.
\end{abstract}

Keyword: Pendekatan Konstruktivisme, Keterampilan Konstruksi, Meningkat

Copyright (C) 2016 IICET (Padang - Indonesia) - All Rights Reserved Indonesian Institute for Counseling, Education and Theraphy (IICET)

\section{PENDAHULUAN}

Kegiatan berkreasi dan berapresiasi memiliki peranan dalam pembentukan pribadi yang harmonis. Artinya, ada keseimbangan antara kemampuan intelegensi, seni, dan keterampilan. Pada pelajaran ini peneliti lebih menekankan pada keterampilan vokasional, khususnya kerajinan tangan. Kerajinan tangan/ keterampilan adalah salah satu bagian dari seni rupa terapan. Sumanto (2006:8) membagi karya seni rupa berdasarkan fungsi/ tujuan menjadi dua yaitu : “(1) Seni rupa murni (fine art) adalah jenis karya seni rupa yang dalam proses penciptaannya mengutamakan ungkapan/ ide/ gagasan, perasaan nilai estetis-artistik; (2) Seni rupa terapan (applied art) adalah jenis karya seni rupa dalam proses penciptaannya lebih mempertimbangkan nilai fungsi”.

Agar tercapainya tujuan pembelajaran kerajinan tangan/ keterampilan konstruksi salah satu cara yang harus digunakan guru dalam proses pembelajaran adalah guru harus menguasai berbagai macam pendekatan. Pendekatan yang digunakan harus sesuai dengan materi yang diajarkan. Kemampuan dan ketepatan guru dalam memilih dan menggunakan pendekatan pembelajaran mempunyai pengaruh yang sangat besar terhadap keberhasilan dan kegairahan belajar peserta didik.

Penggunaan pendekatan dalam pembelajaran adalah untuk menentukan berhasil tidaknya pembelajaran yang diinginkan. Dengan demikian guru diharapkan dapat menggunakan pendekatan-pendekatan dalam pembelajaran sesuai dengan bidang studi dan materi yang diberikan. Menurut Herawati (dalam Asma, 2008:22) terdapat tujuh pendekatan pembelajaran yang sering digunakan guru dalam mengajar peserta didik yaitu "Pendekatan Sains Teknologi Masyarakat (STM), Pendekatan Pemecahan Masalah, Pendekatan Inkuiri, Pendekatan Contextual Teaching and Learning (CTL), Pendekatan Lingkungan, Pendekatan Proses, Pendekatan Konstruktivisme". 
Keterampilan konstruksi bertujuan agar peserta didik mampu bekerja terampil, mampu menciptakan, dan mengekspresikan beragam gagasan/ ide ke dalam suatu karya dengan menggunakan bahan alam dan limbah yang ada di lingkungannya. Untuk mencapai tujuan tersebut, salah satu usaha yang dapat dilakukan untuk meningkatkan proses pembelajaran konstruksi adalah bagaimana seorang guru dapat menciptakan suasana pembelajaran yang dapat membangkitkan kreativitas peserta didik agar keterampilan konstruksi yang dimilikinya mengalami peningkatan dengan baik dan terarah.

Berdasarkan hasil observasi yang dilakukan terhadap peserta didik Kelas IV SD Negeri 04 Batang Anai mengenai pembelajaran keterampilan konstruksi masih termasuk kategori rendah. Rendahnya keterampilan konstruksi tergambar dari hasil karya peserta didik. Selain itu, rancangan keterampilan peserta didik masih serupa antara satu dengan lainnya, dan dalam pelaksanaannya peserta didik masih terpaku pada contoh yang diberikan oleh guru. Ini berarti permasalahannya bukan hanya pada peserta didik saja tapi juga dihadapi oleh guru.

Dalam melakukan penilaian guru cenderung menilai hasil karya peserta didik yang telah tercipta, bukan menilai penerapan pengetahuan dan berfikir yang dimulai dari proses dan kinerja pembuatan hingga diperoleh produk/ hasil. Proses penilaian seperti ini membuat peserta didik berfikir untuk secepatnya menyudahi hasil karya keterampilan konstruksi, tanpa peduli dengan keindahannya. Akibatnya, kemampuan keterampilan konstruksi peserta didik tidak mengalami peningkatan dan permasalahan ini sejalan dengan hasil belajar peserta didik. Permasalahan yang berasal dari peserta didik yaitu peserta didik kurang berupaya untuk mencari bahan dalam pembuatan keterampilan konstruksi. Peserta didik cenderung memanfaatkan sarana/ bahan seadanya.

\section{METODELOGI PENELITIAN}

Penelitian ini dilaksanakan di SD Negeri 04 Batang Anai. Subjek dalam penelitian ini adalah:

a. Peserta didik kelas IV SD Negeri 04 Batang Anai yang terdaftar pada semester II tahun ajaran 2014/2015.

b. Peneliti sebagai guru praktisi pada kelas IV SD Negeri 04 Batang Anai.

c. Guru kelas IV SD Negeri 04 Batang Anai sebagai pengamat.

Penelitian ini dilaksanakan mulai bulan April 2015 dan berakhir pada Juni 2015 yang terdiri dari 2 siklus.

Pendekatan yang digunakan dalam penelitian ini adalah pendekatan kualitatif dan kuantitatif, pendekatan kualitatif digunakan karena peneliti ingin mengamati fenomena yang terjadi di dalam kelas atau proses pembelajaran pada suatu kelas. Jenis penelitian ini adalah penelitian tindakan kelas yaitu proses yang dilakukan perorangan atau kelompok yang menghendaki perubahan dalam situasi tertentu. Menurut Ida (2007:1.4) "Penelitian tindakan kelas adalah penelitian yang dilakukan oleh guru di dalam kelasnya sendiri melalui refleksi diri, dengan tujuan memperbaiki kinerjanya sebagai guru, sehingga hasil belajar peserta didik menjadi meningkat".

Proses penelitian tindakan kelas merupakan proses daur ulang yang diawali dengan perencanaan tindakan, penerapan tindakan, mengobservasi dan mengevaluasi proses dan hasil tindakan, dan melakukan refleksi, dan seterusnya sampai perbaikan atau peningkatan yang diharapkan dapat tercapai.

Kegiatan pelaksanaan penelitian ini terdiri dari tahapan pelaksanaan pembelajaran yang meliputi dua siklus, yakni: perencanaan, pelaksanaan, pengamatan, dan tahap refleksi. Masing-masing kegiatan tersebut diuraikan seperti berikut:

1) Menetapkan jadwal selama penelitian

2) Mengkaji Kurikulum Tingkat Satuan Pendidikan SBK SD, buku paket kelas IV dan buku SBK lainnya yang relevan

3) Menyusun rancangan tindakan berupa rencana pelaksanaan pembelajaran (RPP), hal ini meliputi: standar kompetensi, kompetensi dasar, indikator, materi, metode, proses pembelajaran, media/sumber, evaluasi/penilaian.

4) Menyusun lembaran observasi untuk mencatat aktifitas peserta didik

5) Mendiskusikan dengan guru kelas tentang tata cara pengumpulan data dalam pelaksanaan observasi saat kegitan dilakukan, agar tidak terjadi penyimpangan dalam pengambilan data. Waktu yang digunakan untuk berdiskusi adalah waktu luang yang ada bagi guru misalnya pada jam istirahat, pada waktu pelajaran agama, dan olah raga.

Data penelitian ini berupa hasil pengamatan dari setiap tindakan penggunaan pendekatan konstruktivisme dalam pembelajaran kerajinan tangan/ keterampilan konstruksi pada peserta didik kelas IV SD yang diteliti.

Data penelitian ini dikumpulkan dengan menggunakan pencatatan lapangan, observasi, wawancara dan hasil tes, yang akan diuraikan sebagai berikut 
1. Pencatatan Lapangan, Pencatatan lapangan berupa paparan tentang data pengamatan terhadap praktisi suatu pembelajaran keterampilan konstruksi pada pembuatan vas bunga. Unsur-unsur yang diamati dalam pelaksanaan tertera pada lembaran pengamatan.

2. Observasi, Observasi dilakukan untuk mengamati latar kelas tempat berlangsungnya pembelajaran keterampilan konstruksi pada pembuatan vas bunga. Dengan berpedoman kepada lembaran observasi peneliti mengamati apa yang terjadi selama prsoses pembelajaran.

3. Wawancara, Wawancara digunakan untuk memperkuat data observasi yang terjadi dikelas baik yang berkaitan dengan guru ataupun peserta didik. Wawancara dilakukan pada peserta didik untuk memperoleh data yang berkaitan dengan keterampilan konstruksi pada pembuatan vas bunga. Hal ini dilakukan untuk memperjelas perilaku belajar dan proses berpikir peserta didik selama proses pembelajaran berlangsung.

4. Penugasan, Penugasan digunakan untuk memperkuat data observasi yang terjadi dalam kelas. Dalam penelitian ini, penulis menggunakan dua jenis penugasan yaitu penugasan membuat karya/ keterampilan konstruksi.

Data yang penulis peroleh dalam penelitian dianalisis dengan menggunakan analisis data kualitatif dan kuantitatif. Tahap analisis tersebut diuraikan sebagai berikut:

a) Menelaah data yang terkumpul baik melalui observasi, pencatatan dengan melakukan proses transkripsi hasil pengamatan, penelitian dan pemilahan data. Seperti menggelompokkan data pada siklus I, II, dan seterusnya. Kegiatan menelaah data dilaksanakan sejak awal data dikumpulkan.

b) Reduksi data meliputi kategori dan pengklasifikasian. Semua data yang terkumpul diseleksi dan dikelompokkan sesuai dengan fokus. Data yang telah dipisah-pisahkan tersebut lalu diseleksi mana yang tidak relevan, data yang relevan dianalisis, dan tidak relevan dibuang.

c) Menyajikan data dilakukan dengan cara mengorganisasikan informasi yang sudah direduksi. Data tersebut mula-mula disajikan terpisah, tetapi satelah tindakan terakhir direduksi, keseluruhan data tindakan dirangkum dan disajikan secara terpadu sehingga diperoleh sajian tunggal berdasarkan fokus pembelajaran konstruksi dengan pendekatan konstruktivisme.

d) Mengumpulkan hasil penelitian dan triangulasi. Kegiatan ini merupakan penyimpulan akhir penelitian, diikuti dengan kegiatan triangulasi atau pengujian temuan penelitian. Kegiatan ini dilakukan dengan cara peninjauan kembali catatan lapangan, dan bertukar pikiran dengan ahli, teman sejawat, serta guru dan kepala sekolah.

Hasil dari penelitian ini juga berbentuk angka dan bilangan, jadi dalam pengolahan data digunakan analisis data kuantitatif. Analisis data kuantitatif ini dilakukan terhadap hasil belajar peserta didik dengan menggunakan pendekatan yang dikemukakan oleh Dhydiet (2008:1) dengan rumus sebagai berikut:

$$
\mathrm{P}=\frac{F}{N} \times 100 \%
$$

$$
\begin{aligned}
& \text { Keterangan: } \\
& \mathrm{P}=\text { Persentase } \\
& \mathrm{F}=\text { Frekwensi responden } \\
& \mathrm{N}=\text { Jumlah responden }
\end{aligned}
$$

Taraf keberhasilan ketuntasan tindakan penelitian ini kepada standar ketuntasan belajar minimal menurut BNSP (2006:12) yaitu 75-100\% . Ketetapan standar nasional yang akhirnya dicapai adalah 75\%. Jika belum berhasil maka siklus diteruskan sampai berhasil $75 \%$.

\section{HASIL DAN PEMBAHASAN PENELITIAN \\ HASIL PENELITIAN}

\section{Siklus I}

Siklus I dilaksanakan 2 x pertemuan dengan alokasi waktu 4 x 35 menit. Pada pertemuan pertama dilaksanakan dengan waktu 2 x 35 menit untuk materi hari Senin tanggal 20 April 2015 dan pertemuan kedua dilaksanakan pada hari Senin tanggal 4 Mei 2015 dengan waktu 2 x 35 menit.

Nilai proses yang diambil adalah nilai individu peserta didik selama proses pembelajaran berlangsung, aspek yang diamati adalah kesungguhan dalam bekerja, kelancaran dalam konstruksi, dan keterampilan menggunakan alat. Nilai proses peserta didik dalam pembelajaran keterampilan konstruksi dengan pendekatan konstruktivisme pada siklus I adalah 69\% sehingga dapat dikatakan bahwa penilaian proses pada siklus I ini masih belum tuntas dan harus ditingkatkan pada siklus II. 
Nilai hasil karya peserta didik adalah nilai individu, aspek yang dinilai adalah komposisi/ tampilan, kreasi kontruksi, keindahan, kombinasi bahan. Berdasarkan hasil pengamatan hasil karya konstruksi peserta didik dapat disimpulkan bahwa nilai hasil peserta didik dalam pembelajaran keterampilan konstruksi pada siklus I adalah 62\% sehingga dapat dikatakan bahwa penilaian hasil pada siklusI belum tuntas berdasarkan ketetapan BNSP. Sehingga perlu ditingkatkan lagi pada siklus II dan diharapkan bisa mencapai 75\% atau lebih.

Refleksi dilakukan secara kolaboratif antara penulis, guru kelas yang telah mengadakan pengamatan pada saat pembelajaran keterampilan konstruksi. Refleksi pada tindakan siklus I ini adalah dalam menampilkan model vas bunga seharusnya guru memberikan waktu beberapa menit untuk menampilkan gambar dan model vas bunga agar peserta didik dapat mengamati dan memberikan jawaban tentang keterampilan konstruksi. model vas bunga yang ditampilkan seharusnya lebih dari satu agar peserta didik dapat melakukan perbandingan teknik konstruksi dengan teknik lainnya.

Dari segi perolehan nilai, aspek dalam penilaian proses yang masih perlu ditingkatkan adalah keterampilan peserta didik dalam menggunakan alat untuk pembuatan teknik konstruksi. sedangkan aspek penilaian hasil karya yang masih perlu ditingkatkan adalah aspek keindahan dan kombinasi bahan dan warna. Permasalahan lain adalah sebagian peserta didik masih kurang lengkap membawa alat dan bahan untuk pembuatan keterampilan konstrusksi.

\section{Siklus II}

Tindakan yang dilakukan pada siklus II berpedoman pada hasil refleksi yang dilakukan pada siklus I antara peneliti dengan observer. Kelemahan yang ada akan diperbaiki dan ditingkatkan. Pada siklus II ini, pelaksanaan tindakan dilakukan dalam 2 kali pertemuan. Selama pembelajaran berlangsung, peneliti dengan dibantu oleh dua orang observer mengadakan pengamatan dengan menggunakan lembar observasi yang telah disiapkan. Tujuan dilakukannya siklus II adalah untuk memaksimalkan peningkatan keterampilan kontruksi peserta didik dengan pendekatan konstruktivisme.

Penilaian pada pembelajaran keterampilan konstruksi dengan pendekatan konstruktivisme dilakukan dengan dua cara, yaitu penilaian proses dan penilaian hasil karya konstruksi peserta didik. Penilaian proses dilakukan selama proses pembelajaran berlangsung sedangkan penilaian hasil dilakukan setelah proses pembelajaran berakhir

Nilai proses yang diambil adalah nilai individu peserta didik selama proses pembelajaran berlangsung, aspek yang diamati adalah kesungguhan dalam bekerja, kelancaran dalam konstruksi, dan keterampilan menggunakan alat. Nilai proses peserta didik dalam pembelajaran keterampilan konstruksi dengan pendekatan konstruktivisme pada siklus II adalah $81 \%$ sehingga dapat dikatakan bahwa penilaian proses pada siklus II ini sudah tuntas sesuai dengan ketapan BNSP.

Nilai hasil karya peserta didik adalah nilai individu, aspek yang dinilai adalah komposisi/ tampilan, kreasi kontruksi, keindahan, kombinasi bahan. Penilaian hasil karya peserta didik secara lengkap dapat dilihat pada lampiran 20. Berdasarkan hasil pengamatan hasil karya konstruksi peserta didik, dapat disimpulkan bahwa nilai hasil peserta didik dalam pembelajaran keterampilan konstruksi pada siklus II adalah $81 \%$ sehingga dapat dikatakan bahwa penilaian hasil pada siklusII tuntas berdasarkan ketetapan BNSP.

Berdasarkan hasil observer, peneliti dan observer melakukan refleksi terhadap kegiatan tindakan pada siklus II dengan memperoleh gambaran bahwa pelaksanaan pembelajaran konstruktivisme pada siklus II berada pada kategori sangat baik. Demikian juga dengan penilaian aktivitas guru dan peserta didik. Penilaian proses dan penilaian hasil karya peserta didik mengalami peningkatan. Hal ini menandakan bahwa dengan menggunakan pendektan konstruktivisme, keterampilan konstruksi peserta didik meningkat. Peningkatan yang terjadi sudah sesuai dengan yang diharapkan.

\section{PEMBAHASAN}

Rancangan pembelajaran merupakan langkah awal yang dilakukan oleh guru sebelum proses pembelajaran berlangsung. Rancangan pembelajaran memberikan peranan yang sangat penting dalam menentukan keberhasilan sebuah proses pembelajaran. Rancangan merupakan pemandu bagi guru dalam melaksanakan tugas di kelas. Rancagan pembelajaran yang tepat dan efektif membutuhkann guru yang kreatif.

Kegiatan awal pembelajaran atas pernyataan yang mencerminkan kegiatan kesiapan peserta didik memulai pembelajaran, media, dan tujuan pembelajaran, hingga skemata. Kegiatan inti pembelajaran merupakan kegiatan yang rinci dan runtut yang mencerminkan keterlibatan peserta didik sebagai subjek. Kegiatan akhir pembelajaran terdiri kesimpulan materi, dan tindak lanjut.

Pelaksanaan pembelajaran dilakukan sesuai dengan rencana yang telah ditetapkan. Pembahasan tindakan terhadap pelaksanaan pembelajaran keterampilan konstruksi dengan pendekatan konstruktivisme siklus I 
meliputi: 1) kegiatan awal pembelajaran, 2) kegiatan inti pembelajaran dengan menggunakan langkah-langkah konstruktivisme, dan 3) kegiatan akhir pembelajaran yang meliputi penilaian proses dan hasil.

Berdasarkan hasil pengamatan penilaian keterampilan konstruksi pembuatan vas bunga dengan pendekatan konstruktivisme pada siklus I diperoleh penilaian proses dengan nilai rata-rata 62 dan penilaian hasil rata-rata 69. Keberhasilan penilaian seluruh peserta didik dalam pembelajaran keterampilan konstruksi dengan pendekatan konstruktivisme pada siklus I yaitu 67. Penilaian pembelajaran keterampilan konstruksi dengan pendekatan konstruktivisme pada siklus I ada 1 orang peserta didik yang tuntas dan 30 orang yang belum tuntas dalam pembelajaran.

Dalam penelitian tindakan ini, hal yang dilakukan adalah meningkatkan keterampilan konstruksi peserta didik kelas IV. Rancangan pembelajaran yang efektif dan penggunaan yang tepat memungkinkan untuk tercapainya tujuan dan ditunjang dengan pendekatan yang tepat pula seperti pendekatan konstruktivisme. Tindakan pada siklus II ini diperoleh hasil karya konstruksi yang bagus dan indah.

Pelaksanaan pembelajaran dilakukan sesuai dengan rencana yang telah ditetapkan. Hal yang harus menjadi catatan dalam penerapan pendekatan konstruktivisme adalah: a) peserta didik belajar melalui interaksi dengan guru atau teman, b) konsep itu berada dekat dengan peserta didik, c) peserta didik memperoleh ilmu secara bertahap, d) diberikan tugas kompleks, sulit, dan realita kemudian baru diberi bantuan (Mohammad, 2004:4) keempat hal inilah yang menjadi pertimbangan dalam proses pelaksanaan pembelajaran menggunakan pendekatan konstruktivisme.

Pembelajaran pada siklus II dimulai dengan kegiatan skemata dan permodelan. Guru memajang gambar vas bunga yang sesuai dengan materi pembelajaran. Selanjutnya, guru meminta pendapat peserta didik mengenai gambar yang ditampilkan. pada saat gambar ditampilkan, peserta didik langsung bertanya gambar apa itu? Apa bahan dan alat yang digunakan untuk membuatnya? Sehingga skemata peserta didik menjadi berkembang.

Pelaksanaan tindakan dilanjutkan dengan kegiatan inti dengan menggunakan langkah-langkah konstruktivisme yaitu pengaktifan pengetahuan yang sudah ada dilakukan dengan tanya jawab tentang bahan alam dan limbah kemudian guru menampilkan bahan alam dan limbah. Perolehan pengetahuan dilakukan dengan menampilkan vas bunga dan melakukan pengamatan kepada vas bunga yang ditampilkan dan melakukan tanya jawab. Langkah berikutnya pemahaman pengetahuan dilakukan dengan cara menampilkan berbaga model vas bunga dengan teknik yang berbeda dan menugaskan peserta didik untuk mengamati vas bunga yang ditampilkan dan menyebutkan langkah-langkah konstruksi pada pembuatan vas bunga model II. Langkah berikutnya menerapkan pengetahuan dan pengalaman yang diperolehnya dengan membuat vas bunga model II selanjutnya dilakukan refleksi yaitu pengoreksian terhadap hasil karya temannya. Kegiatan akhir, guru membimbing peserta didik untuk menyimpulkan hasil pembelajaran hingga peserta didik bisa melakukan penyimpulan sendiri.

Dalam siklus II ini pelaksanaan yang dirancang sudah terlaksana, selesainya hasil karya peserta didik tepat pada waktunya dan kegiatan yang tidak terlaksana pada siklus I terlaksana pada siklus II seperti penampilan bahan alam dan limbah serta terlihatnya kegiatan tanya jawab tentang keterampilan konstruksi dan mampunya peserta didik membedakan vas bunga dengan teknik konstruksi.

Dalam pembelajaran konstruktivisme, penilaian dapat dilakukan melalui penilaian proses dan penilaian hasil. Penilaian proses dan penilaian hasil inilah yang digunakan dalam penelitian ini. Untuk menentukan nilai diperlukan adanya ukuran atau kriteria yang dijadikan dasar. Kriteria penilaian proses yaitu kesungguhan dalam bekerja, keterampilan menggunakan alat, kelancaran dalam konstruksi. Sedangkan kriteria penilaian hasil yaitu tampilan, kreasi konstruksi, keindahan, dan kombinasi.

Penilaian proses dalam pembelajaran keterampilan konstruksi pada peserta didik kelas IV SD meningkat pada siklus II yaitu dengan nilai proses rata-rata 81 sedangkan penilaian hasil rata-rata adalah 81 . keberhasilan penilaian seluruh peserta didik dalam pembelajaran keterampilan konstruksi dengan pendekatan konstruktivisme pada siklus II yaitu dengan rata-rata 81. Penilaian peningkatan keterampilan konstruksi dengan pendekatan konstruktivisme pada siklus II terdapat 4 orang peserta didik yang belum tuntas dan 27 orang peserta didik yang tuntas.

\section{KESIMPULAN DAN SARAN \\ KESIMPULAN}

Dari paparan hasil penelitian dapat disimpulan yang dapat diambil dari penelitian ini adala sebagai berikut:

a) Rancangan pembelajaran dalam proses pembelajaran keterampilan konstruksi dengan menggunakan pendekatan konstruktivisme dituangkan dalam bentuk RPP yang komponen penyusunannya terdiri dari standar kompetensi, kompetensi dasar, indikator, materi pembelajaran, proses pembelajaran, media dan sumber pembelajaran, dan penilaian pembelajaran. 
b) Pelaksanaan pembelajaran keterampilan konstruksi dengan menggunakan pendekatan konstruktivisme terdiri dari: kegiatan awal pembelajaran, kegiatan inti dan kegiatan akhir.

c) Penilaian pembelajaran keterampilan konstruksi dengan pendekatan kostruktivisme pada peserta didik kelas IV SD Negeri 04 Batang Anai adalah penilaian proses dan hasil karya peserta didik. Penilaian proses dan hasil karya peserta didik meningkat secara bertahap dari siklus I hingga siklus II, dengan rata-rata siklus I adalah $67 \%$ dan rata-rata siklus II adalah $81 \%$.

\section{SARAN}

Dari hasil penelitian dapat diajukan saran sebagai berikut:

a) Kepala Sekolah hendaknya dapat memotivasi dan membina guru-guru untuk menggunakan pendekatan konstruktivisme dalam pembelajaran di sekolah dan memantau proses pelaksanaannya.

b) Guru hendaknya pendekatan konstruktivisme dapat dijadikan sebagai salah satu alternatif dalam pembelajaran SBK dan sebagai suatu pendekatan yang dapat digunakan untuk meningkatkan kemampuan peserta didik.

c) Peneliti lain, yang merasa tertarik dengan pendekatan konstruktivisme agar dapat melakukan penelitian dengan menggunakan pendekatan konstruktivisme dengan menggunakan materi yang lain.

\section{DAFTAR PUSTAKA}

Ari Subekti, S.Pd, dkk. 2006. Seni Budaya dan Keterampilan. Klaten: PT. Intan Pariwara

Depdiknas. 2006. Badan Standar Nasional Pendidikan. Jakarta: Depdiknas

Ella Yulaelawati. 2004. Kurikulum dan Pembelajaran. Bandung: Pakar Raya

Ida Wardhani,dkk. 2007. Penelitian Tindakan Kelas. Jakarta:UT

Mohammad Nur. 2004. Pengajaran Berpusat Kepada Siswa dan Pendekatan Konstruktivisme dalam Pengajaran. Jakarta: Universitas Negeri Surabaya 